\title{
ЗАСТОСУВАННЯ ІННОВАЦІЙНИХ ТЕХНОЛОГІЙ ПІД ЧАС ЛЕКЦІЇ
}

\author{
Р. М. Байраченко
}

\author{
Одеське обласне базове медичне училище
}

У статті відображено сучасні уявлення про організацію і проведення лекції-візуалізації, широке впровадження інформаційних технологій в навчальний процес. Виділено основні етапи лекції, матеріали активізації студентів під час викладання лекції.

\section{APPLICATION OF INNOVATIVE TECHNOLOGIES DURING A LECTURE}

\section{R. M. Bayrachenko}

\section{Odesa Regional Basic Medical College}

The article reflects modern ideas concerning an organization and conduction of lection-visualization, broad implementation of information technologies in learning process. The main stages of lecture, materials of enhancing students during lecture process have been allocated.

Вступ. Одним із основних шляхів підвищення якості вищої освіти є широке впровадження інноваційних технологій навчання, серед яких важливе місце належить інформаційним технологіям (IT).

Аналіз наукових джерел засвідчує, що в дидактиці вищої школи накопичено значний досвід використання IT, однак питання їх ефективного застосування під час лекції в процесі вивчення дисциплін ще не стало предметом ґрунтовних наукових досліджень [3-5].

На підставі аналізу психолого-педагогічної літератури лекція являє собою чіткий і систематизований виклад матеріалу, сконцентрований навколо фундаментальних проблем науки та ілюстрований сучасними технічними засобами навчання. Використання IT у вищій школі під час лекційних занять має на меті реалізацію таких завдань: розвиток системності мислення студентів; підтримка усіх видів пізнавальної діяльності; закріплення знань; реалізація принципу індивідуалізації навчання при збереженні його цілісності $[1,2]$.

Широке впровадження IT у навчальний процес сприяло появі лекцій інноваційного типу: лекціявізуалізація, лекція із мультимедійним супроводом, відеолекція.

Основна частина. Лекція виконує певні функції [1]:

- інформаційна передбачає передавання адаптованої для студентів інформації;

(c) Р. М. Байраченко , 2016
- орієнтовна розкриває генезис теорій, ідей: коли, ким вони вивчалися, якими причинами спонукались; список рекомендованої літератури до лекції;

- пояснювальна, роз'яснювальна передбачає розкриття сутності наукових понять, їх визначень, тлумачення кожного слова, що належать до структури визначення;

- переконувальна полягає у використанні аргументації, логічної доказовості, на основі чого усвідомлюється наукова інформація, що стає базою для формування у студентів наукових поглядів і переконань;

- систематизовувальна передбачає структурування всього масиву знань з певної дисципліни;

- стимулювальна спрямована на пробудження інтересу до навчальної інформації з певної науки;

- виховна і розвивальна передбачає оцінювання явищ, фактів, процесів, які розглядаються на лекції, розвиток мислення, уваги, уяви, пам'яті та інших пізнавальних здібностей.

Лекції повинні відповідати таким вимогам: моральність змісту лекції і викладача, науковість, інформаційність, доказовість і аргументованість, емоційність викладу інформації, активізація мислення слухачів через запитання для роздумів; чітка структура і логіка розкриття інформації; методичне оброблення, тобто виведення головних думок і положень, висновків, повторення їх у різних формулюваннях; викладання 
доступною і зрозумілою мовою; використання аудіовізуальних дидактичних матеріалів тощо.

Лектор зобов'язаний вміти правильно визначати настрій аудиторії, рівень дохідливості змісту лекції і рівень його засвоєння не лише за явно вираженою зовнішньою реакцією, а й за малопомітними ознаками поведінки аудиторії. За усмішкою, кивком голови, запитальним поглядом, зміною пози викладач повинен оцінити стан партнера по взаємодії і при необхідності одразу внести необхідні корективи в намічений план лекції.

Цінність лекції полягає в тому, що у її процесі студент має змогу засвоїти значно більше інформації, ніж за той самий час самостійної роботи. Під час лекції формуються погляди й переконання студентів, уміння критично оцінювати здобуту інформацію. Лекція сприяє також встановленню прямого контакту між викладачем і студентами, своєчасному інформуванню студентів про новітні наукові досягнення тощо.

На лекції розглядають найгостріші проблемні та вузлові питання, висвітлюють шляхи розв'язання проблем сучасною наукою і практикою, розглядають важкі для самостійного опрацювання студентами питання навчальної програми. Студент у процесі лекції може отримати відповідь на будь-яке запитання, що дасть йому змогу повноцінно включитися в навчальнопізнавальну діяльність.

Види лекцій. Лекції класифікують за кількома критеріями.

1. За дидактичними завданнями лекції поділяють на вступні: тематичні, настановчі, оглядові, заключні $[6,7]$.

Вступна лекція зорієнтована на те, щоб дати студентам загальне уявлення про завдання і зміст усієї навчальної дисципліни, розкрити її структуру й логіку розвитку конкретної галузі науки, техніки, культури, взаємозв'язок з іншими дисциплінами, а також сприяти зацікавленості предметом. На такій лекції важливо розкрити значення дисципліни у фаховій підготовці спеціаліста, ії̈ зв'язок з іншими навчальними дисциплінами. Окрім того, вступна лекція повинна орієнтувати студентів на те, як потрібно слухати лекції, як їх конспектувати, як працювати над першоджерелами, які теми курсу вивчати самостійно. Зміст настанов викладача визначається тим, на якому курсі читається ця лекція.

2. За способом викладу навчального матеріалу виокремлюють такі види лекції: проблемні лекції, лекції-візуалізації, бінарні лекції, або лекції-дискусії, лекції із заздалегідь запланованими помилками, лекції-прес-конференції.

Лекція-візуалізація (від лат. visualis - зоровий) виникла як результат пошуку нових можливостей реалізації принципу наочності. Викладач на такій лекції використовує демонстраційні матеріали, форми наочності, які не лише доповнюють словесну інформацію, а й самі виступають носіями змістовної інформації. Читання ії зводиться до вільного, розгорнутого коментування підготованих матеріалів. У візуальній лекції важливі візуальна логіка, ритм подачі матеріалу, його дозування, майстерність і стиль спілкування викладача з аудиторією.

Лекція вимагає від студента зосередженості уваги на науковій інформації, яку подає викладач. Тільки в такому разі він свідомо засвоюватиме навчальний матеріал, виявлятиме зацікавленість до різних наукових питань.

Лекція-візуалізація - одна із лекцій інноваційного типу. Ії̈ особливістю $є$ наявність умов для реалізації повною мірою принципу наочності. Зазначений тип лекції сприяє навчанню студентів перетворювати усну й письмову інформацію у візуальну форму, що завдяки систематизації й виокремленню найбільш значущих, суттєвих елементів змісту навчання формує у них професійне мислення.

Процес візуалізації являє собою згортання мисленнєвих операцій шляхом утворення на основі різних видів інформації наочного образу, який може слугувати опорою для розумових і практичних дій.

Здатність візуальної інформації впливати на усвідомлення та розуміння нової інформації сприяє формуванню лінгвокогнітивних умінь. Цей вплив може бути більш ефективним, якщо відеоматеріал використовується викладачем не як візуальний коментар словесної інформації, а як комплекс проблемних завдань, що веде до активної розумової діяльності суб'єктів навчання.

Таким чином, лекція-візуалізація - це не лише передання усної інформації, перетвореної у візуальну форму за допомогою мультимедійних засобів, а й слугує засобом організації інтелектуальної діяльності студентів. Підготовка такої лекції полягає в реконструюванні, перекодуванні змісту лекції або її частин у візуальну форму для презентації через комп'ютер. Головне завдання такого типу лекції - максимально полегшити сприймання складного мовознавчого матеріалу, коли необхідно не тільки враховувати ключові поняття і фрази, базові визначення, а й усвідомлювати характер відношень між ними. 
Різновидом лекції-візуалізації можна вважати відеолекцію. Вона являє собою зняту та записану на диск скорочену лекцію провідного вченого, доповнену схемами, таблицями, фотографіями, що ілюструють науковий теоретичний матеріал.

Наводимо методичний сценарій лекції-візуалізації на тему: «Анатомо-фізіологічні особливості недоношеної новонародженої дитини та догляд за нею». Визначається актуальність теми, навчальні цілі та мотивація, презентується мета лекції.

План лекції:

1. Визначення недоношеності та її причини, ознаки недоношеної дитини.

2. Організація медичного обслуговування та принципи виходжування недоношених дітей згідно з чинними наказами МОЗ України.

3. Вигодовування недоношених дітей.

4. Принципи диспансеризації.

Оформлені слайди відповідно до питань:

1. Визначення недоношеності.

2. Причини недоношеності.

3. Особливості недоношеної дитини.

4. Основні розлади адаптації та патологічні стани недоношених дітей.

5. Шкала Сільвермана.

6. Особливості фізичного і психомоторного розвитку.

7. Організація медичного обслуговування і принципи виходжування недоношених дітей.

8. Пологова зала.

9. Особливості догляду за недоношеною дитиною.

10. Оцінювання адаптації недоношеної дитини після народження та алгоритм дій лікаря.

11. Тепловий ланцюжок.

12. 10 критеріїв теплового ланцюжка.

13. Рекомендована температура для утворення нейтрального температурного середовища в інкубаторі.

14. Спільне перебування матері та дитини, народженої з нормальною масою тіла.

15. Зважування.

16. Вимірювання температури тіла дитини.

17. Обов'язки середнього медперсоналу.

18. Догляд за дитиною, народженою з малою масою тіла, після операції кесаревого розтину.

19. Профілактичні заходи.

20. Годування новонародженої дитини з малою масою тіла при народженні.

21. Вигодовування недоношених дітей.
22. Добова загальна кількість молока або іншої рідини залежно від віку.

23. Вибір методу годування.

24. Годування через зонд.

25. Догляд за новонародженими з малою масою тіла при народженні за методом «мати-кенгуру».

26. Завдання методу «мати-кенгуру».

27. Переваги методу «мати-кенгуру».

28. Різновиди методу «мати-кенгуру».

29. Критерії, які визначають готовність дитини до використання методу «мати-кенгуру».

30. Догляд і спостереження за дитиною під час проведення методу «мати-кенгуру».

31. Практичні аспекти впровадження методу «матикенгуру».

32. Кенгуру-позиція.

33. Скринінгові обстеження новонароджених із малою масою тіла при народженні.

34. Обстеження новонароджених з малою масою тіла при народженні на вроджений гіпотиреоз (ВГТ).

35. Щеплення дитини з малою масою тіла при народженні.

36. Щеплення новонароджених проти туберкульозу.

37. Критерії виписки дитини з малою масою тіла при народженні.

38. Заповнення медичної документації.

Текстова інформація супроводжується показом наочних картинок, схем, фотографій відповідно до теми. Засоби візуалізації покращують сприйняття нової інформації, дозволяють посилити збереження отриманої інформації в пам'яті, демонструють естетичні вимоги та потреби суб'єкта навчального процесу.

Для активізації студентів під час викладання лекції доцільно використовувати метод «мозкового штурму», який розвиває вміння швидко розв'язувати нестандартні професійні задачі та знаходити вихід із критичних ситуацій, спонукає до активної та продуктивної праці.

Контрольні запитання з теми: «Анатомо-фізіологічні особливості доношеної новонародженої дитини та догляд за нею»:

1. Дайте визначення доношеної новонародженої дитини.

2. Які ознаки доношеної новонародженої дитини?

3. Як виглядає фізіологічна еритема?

4. Де розташоване кільце пупкового канатика у доношеної новонародженої дитини?

5. Які розміри великого тім'ячка у доношеної дитини? 
6. Чим зумовлена фізіологічна втрата маси тіла у дитини?

7. Чому в новонароджених дітей спостерігається токсична еритема?

8. Унаслідок чого розвивається фізіологічна жовтяниця у доношених дітей?

9. Чому в новонароджених спостерігається транзиторна гіпертермія?

10. Що означає сечокислий інфаркт нирок?

11. Яка частота дихань за 1 хв у доношеної новонародженої дитини?

12, За який термін часу оцінюють стан новонароджених за шкалою Апгар?

13. Як проявляються статеві кризи у доношених новонароджених?

14. Які причини розвитку транзиторного катару кишок у доношених новонароджених?

15. Що означає «мілія» та «міліарія»?

16. Які анатомо-фізіологічні особливості шкіри у доношених новонароджених дітей?

17. Коли здійснюють вакцинацію проти гепатиту $B$ доношеним новонародженим дітям?

18. Яка частота серцевих скорочень за 1 хв у доношеної новонародженої дитини?

19. За якими симптомами оцінюють стан новонароджених за шкалою Апгар?

20. Коли потрібно вимірювати температуру тіла у новонароджених?

\section{ЛІТЕРАТУРА}

1. Фіцула М. М. Педагогіка вищої школи : навч. посіб. / М. М. Фіцула. - К. : Академвидав, 2014.

2. Мілерян В. Є. Методичні основи підготовки та проведення навчальних занять у медичних вузах : метод. посіб. / В. Є. Мілерян. - К. : Хрещатик, 2006. - 80 с.

3. Благодаренко Л. Ю. Підвищення педагогічної ефективності навчання фізики в основній школі під час використання мультимедійних технологій [Електронний ресурс] / Л. Ю. Благодаренко. - Режим доступу : Загол. з екрана.

4. Голета О. О. Применение информационных технологий в образовании [Электронный ресурс] /
21. Колиздійснюють вакцинацію проти туберкульозу доношеним новонародженим дітям?

22. Протягом якого часу відбувається контакт матері і дитини «шкіра до шкіри»?

23. Що охоплює тепловий ланцюжок?

24. Які правила виписування доношеної новонародженої дитини з пологового будинку?

\section{Матеріали контролю засвоєння теми.}

\section{Заключний етап.}

1. Резюме лекції, загальні висновки.

2. Відповіді на можливі запитання.

3. Завдання для самопідготовки студентів.

Висновки. Візуально представлений навчальний матеріал має забезпечити систематизацію наявних у студентів знань, надання можливостей для аналізу і синтезу, класифікацію іузагальнення навчального матеріалу, створення проблемних ситуацій іумов їхнього вирішення, що є важливим для процесу формування лінгвокогнітивних умінь.

Дещо відрізняється від лекції-візуалізації лекція із мультимедійним супроводом. Вона являє собою лекцію, під час якої викладач фрагментарно спирається на мультимедійні засоби (тоді як лекція-візуалізація це низка взаємозалежних відеофрагментів).

Таким чином, лекція інноваційного типу дозволяє інтенсифікувати діяльність суб'єктів навчання; підвищувати якість засвоєння матеріалу; зосереджувати увагу на найбільш важливих (з точки зору навчальних завдань і цілей) характеристиках досліджуваних об'єктів.

О. О. Голета. - Режим доступу : < http://ito.edu.ru/2006> Загол. з екрана.

5. Григорьев О. А. Информатизация образования [Электронный ресурс] / О. А. Григорьев. - Режим доступу: < http://ito.edu.ru/2006> Загол. з екрана.

6. Психологія та педагогіка: підручник / [М. Б. Максименко, С. Д. Євтух, В. В. Коваленко та ін.] ; за ред. С. Д. Максименка. - К. : Слово, 2013. - 578 с.

7. Панфілова О. П. Мозкові штурми у колективному ухваленні рішень / О. П. Панфілова. - Спб. : Питер, 2005. 